
\title{
$\begin{array}{ll}\text { Research Square } & \begin{array}{l}\text { Preprints are preliminary reports that have not undergone peer review. } \\ \text { They should not be considered conclusive, used to inform clinical practice, } \\ \text { or referenced by the media as validated information. }\end{array}\end{array}$
}

\section{Fruit Evaluation of 103 Acerola (Malpighia Emarginata D. C.) Phenotypes from the Subtropical Region of Brazil}

\section{Daniela Farinelli ( $\sim$ daniela.farinelli@unipg.it )}

Universita degli Studi di Perugia Dipartimento di Scienze Agrarie Alimentari e Ambientali https://orcid.org/0000-0002-7791-6987

\section{Portarena Silvia}

Istituto di Ricerca sugli Ecosistemi Terrestri Consiglio Nazionale delle Ricerche

\section{Daniel Fernandes Silva}

UNIOESTE: Universidade Estadual do Oeste do Parana

\section{Traini Chiara}

University of Perugia: Universita degli Studi di Perugia

\section{Silva Giordana Menegazzo}

UNIOESTE: Universidade Estadual do Oeste do Parana

\section{Silva Edvan Costa}

UNIOESTE: Universidade Estadual do Oeste do Parana

\section{Veiga Joice Ferreira}

UNIOESTE: Universidade Estadual do Oeste do Parana

\section{Pollegioni Paola}

Istituto di Ricerca sugli Ecosistemi Terrestri Consiglio Nazionale delle Ricerche

Villa Fabiola

UNIOESTE: Universidade Estadual do Oeste do Parana

\section{Research Article}

Keywords: ascorbic acid, polyphenols, breeding program, heat map, dissimilarity, pulp yield

Posted Date: May 4th, 2021

DOI: https://doi.org/10.21203/rs.3.rs-438729/v1

License: (9) (1) This work is licensed under a Creative Commons Attribution 4.0 International License. Read Full License 


\section{Abstract}

Acerola fruit is one of the richest natural sources of ascorbic acid ever known. As a consequence, acerola fruit and its products are demanded worldwide for the production of health supplements and for the development of functional products. Acerola phenotypes (103) were selected from Western Paraná State and evaluated to obtain information on fruit quality characteristics with the aim of using them in genetic breeding programs for improving acerola in the subtropical region of Brazil. Multivariate analysis of the dissimilarity among the phenotypes was performed using the heat map clustering method and principal component analysis. Results obtained using the two methods were comparable, and the methods were effective in discriminating between samples and variables. This indicates variability among phenotypes with potential for its use in breeding programs. Based on the mean values of the chemical and physical characteristics of fruits and considering the differences among the phenotypes, nine crosses are suggested to generate a future improved population, namely between phenotype numbers $37,4,14,29$ and phenotype numbers 99,60 and 66 , belonging to the two different clusters and characterized by high vitamin $\mathrm{C}$ content and yield or higher values of fruit size and color parameters.

\section{Highlights}

- Initial characterization of acerola phenotypes in the subtropical region of Brazil

- Analysis of the dissimilarity of phenotypes by the heat map clustering method and PCA

- Negative correlation was found between $\mathrm{pH}$ and color parameters

- Color traits showed the highest number of correlations with the parameters studied

- Vitamin C and polyphenols were significantly correlated

\section{Introduction}

Acerola (Malpighia emarginata D.C.) is a tropical species, native to the Caribbean Islands and is adapted to the Northeastern region of Brazil (Ritzinger and Ritzinger 2011). The fruit is considered a super-fruit due to its high ascorbic acid content (vitamin $\mathrm{C}$ ) that can reach up to $5 \%$ in the flesh (Mezadri et al. 2008; Prakash and Baskaran 2018), which is about 80 times more than the amount in oranges and lemons (Rekha et al. 2012; de Ancos et al, 2016).

In addition to vitamin C, acerola contains many other functional substances such as phenols, anthocyanins and carotenoids that make it a healthy food (de Assis et al. 2008; Xu et al. 2020). The fruit may be consumed fresh or used in the processing of several food products, especially in the pharmaceutical industry for vitamin C and phenol extraction, and as a foodstuff supplement (Segtowick et al. 2013; Reis et al. 2017; Belwal et al. 2018; Prakash and Baskaran 2018). The amount of vitamin $C$ and phenols in acerola are generally the result of a complex combination of multiple factors such as cultivar, environment, and conditions of cultivation and storage (Gomes et al. 2000; Semesato and Pereira 2000; Chitarra and Chitarra 2005; Hanamura et al. 2008; Maciel et al. 2010; Mariano-Nasser et al. 2017; Ribeiro and de Freitas 2020).

To date, Brazil is the world's largest producer of acerola (de Assis et al, 2008) with more than 7000 hectares under cultivation. Among the various States, the most important are: Bahia (1466 ha), Paraná (919 ha), Rio Grande do Norte (800 ha), Rondnia (723 ha), Pernambuco (604 ha), Minas Gerais (466 ha), San Paulo (423 ha), Paraaba (400 ha), Cear (320 ha) and Para (300 ha) (Calgaro and Brandão 2012 ).

Recently there has been an increase in the demand for acerola in domestic and international markets, especially in the Northern hemisphere, mainly due to the promotion of functional food consumption. The increased demand, especially by the pharmaceutical industry, has boosted the establishment of new orchards (de Araujo Ferreira et al. 2009; Ritzinger and Ritzinger 2011).

There are more than 42 acerola cultivars planted throughout Brasil, such as Apodi, Cabocla, Cereja, Frutacor, Okinawa, Oliver, Rochinha, Rubra and Sertaneja (Figueiredo Neto et al. 2014). Among those, Okinawa, Sertaneja and Flor Branca are present in Minas Gerais, Sergipe, Bahia and Pernambuco States and Olivier and Waldy - CATI 30 in San Paulo State (Furlaneto and Nasser 2015; Ritzinger and Ritzinger 2011). In addition, some cultivars have been released in San Paulo State, such as Sertaneja, Olivier, UEL3- Dominga, UEL4-Lìgia, UEL5Natalì, UFRPE-7 and UFRPE-8 (Cavalcante et al. 2007). Other varieties such as Flor Blanca and BRS 366 have been released for the soil conditions in the country's northeastern region (Pacajùs -CE) (Souza et al. 2014). Other varieties (BRS 235 - Apodi, Mirandópolis, Waldy CATI 30, BRS 238 - Frutacor, Okinawa, BRS 236 - Cereja and BRS 237 - Roxinha) have been released from the Active Bank Germplasm APTA Regional Alta Paulista (Mariano-Nasser et al. 2017) (Fig. 1).

In the Western region of the Paraná State, in the Southern region of Brazil, acerola plantations are quite recent and they are expanding slightly. In this region, based on Köppen climate classification, the climate is of the Cfa type, that is, humid subtropical mesothermal

Page 2/22 
(Alvares et al. 2013). Annual rainfall varies from 1600 to $1800 \mathrm{~mm}$, with rainfall well distributed throughout the year and hot summers. The annual average temperature in the region is between $22^{\circ} \mathrm{C}$ and $23^{\circ} \mathrm{C}$ (Caviglione et al. 2000). Acerola plantations were established using a few cultivars selected from other geo-climatic areas, such San Paulo or other foreign States. Its propagation from seedlings, resulted in highly heterogeneous orchards in terms of fruit quality and yield (Ritzinger et al. 2018). This led to some disadvantages such as the segregation of plant and fruit characteristics, making certatin farming practices difficut, in particular the harvesting systems (Gomes et al. 2000; Moura et al. 2007; Oliveira et al. 2009).

Although the fruit quality parameters of acerola from different States of Brazil have been reported (Table 1), only one study reported the biochemical and morphological characterization of 14 clones grown in the commercial orchards of Northern Paraná, usable for a breeding program (Carpentieri-Pípolo et al. 2000). 
Table 1

Ranges of the principal acerola chemical characteristics reported in literature by studies carried out in several States of Brazil, referred to ripe fruits

\begin{tabular}{|c|c|c|c|c|c|c|c|c|c|}
\hline Location & $\begin{array}{l}\text { Geographic } \\
\text { coordinates }\end{array}$ & Cultivar & $\begin{array}{l}\text { Vitamin } \\
\text { C } \\
\text { Content } \\
\text { (mg/100 } \\
\text { g pulp) }\end{array}$ & $\begin{array}{l}\text { Soluble } \\
\text { Solids } \\
\text { Content } \\
\text { ( Brix) } \\
\text { (SSC) }\end{array}$ & $\begin{array}{l}\text { Titratable } \\
\text { Acidity } \\
\text { (\%) (TA) }\end{array}$ & $\begin{array}{l}\text { SSC/TA } \\
\text { ratio }\end{array}$ & $\mathrm{pH}$ & $\begin{array}{l}\text { Total } \\
\text { Polyphenols } \\
\text { (mg/kg } \\
\text { gallic acid) }\end{array}$ & References \\
\hline $\begin{array}{l}\text { Anápolis, } \\
\text { Goiás State GO }\end{array}$ & $\begin{array}{l}1000 \mathrm{~m} \\
\text { a.s.l. }\end{array}$ & 9 genotypes & $\begin{array}{l}348- \\
1503\end{array}$ & $\begin{array}{l}5.4- \\
8.27\end{array}$ & $\begin{array}{l}7.5-17.4 \\
(\mathrm{ml})\end{array}$ & $\begin{array}{l}0.40- \\
0.95\end{array}$ & $\begin{array}{l}2.34- \\
3.15\end{array}$ & & $\begin{array}{l}\text { Semensato } \\
\text { and Pereira } \\
(2000)\end{array}$ \\
\hline $\begin{array}{l}\text { Cruz das } \\
\text { Almas Bahia } \\
\text { State BA }\end{array}$ & & $\begin{array}{l}\text { CMF 017, } \\
\text { Rubra, } \\
\text { Cabocla }\end{array}$ & $\begin{array}{l}911- \\
1192\end{array}$ & $\begin{array}{l}7.88- \\
8.84\end{array}$ & $\begin{array}{l}0.83- \\
1.35\end{array}$ & $\begin{array}{l}5.84- \\
10.71\end{array}$ & $\begin{array}{l}3.29- \\
3.60\end{array}$ & & $\begin{array}{l}\text { Godoy de } \\
\text { et al. } \\
(2008)\end{array}$ \\
\hline $\begin{array}{l}\text { Carpina/ } \\
\text { Pernambuco } \\
\text { State PE }\end{array}$ & $\begin{array}{l}7^{\circ} 51^{\prime} 04^{\prime \prime} \\
\text { S, } 35^{\circ} 14^{\prime} \\
27^{\prime \prime} \mathrm{W} \\
178 \mathrm{~m} \mathrm{a.} \\
\text { s.l. }\end{array}$ & 12 genotypes & $\begin{array}{l}1057- \\
2032\end{array}$ & $\begin{array}{l}6.2- \\
10.3\end{array}$ & $\begin{array}{l}1.09- \\
1.89\end{array}$ & $4.4-6.4$ & $\begin{array}{l}2.98- \\
3.37\end{array}$ & & $\begin{array}{l}\text { Musser et } \\
\text { al. (2004) }\end{array}$ \\
\hline $\begin{array}{l}\text { Petrolina, } \\
\text { Pernambuco } \\
\text { State PE }\end{array}$ & & 42 genotypes & $\begin{array}{l}779- \\
2444\end{array}$ & $5.3-9.2$ & $\begin{array}{l}0.79- \\
1.90\end{array}$ & & $\begin{array}{l}3.11- \\
3.70\end{array}$ & & $\begin{array}{l}\text { Gonzaga } \\
\text { Neto et al. } \\
(1999)\end{array}$ \\
\hline $\begin{array}{l}\text { Petrolina, } \\
\text { Pernambuco } \\
\text { State PE }\end{array}$ & & $\begin{array}{l}\text { Flor Branca, } \\
\text { Okinawa and } \\
\text { Sertaneja }\end{array}$ & $\begin{array}{l}1786- \\
3597\end{array}$ & $\begin{array}{l}8.43- \\
12.7\end{array}$ & & & & & $\begin{array}{l}\text { Figueiredo } \\
\text { Neto et al. } \\
(2014)\end{array}$ \\
\hline $\begin{array}{l}\text { São Francisco } \\
\text { Valley, } \\
\text { Petrolina, } \\
\text { Pernambuco } \\
\text { State PE }\end{array}$ & $\begin{array}{l}09^{\circ} 09^{\prime} \mathrm{Se} \\
40^{\circ} 22^{\prime} \mathrm{W} . \\
365 \mathrm{~m} \text { a.s.l. }\end{array}$ & $\begin{array}{l}\text { Flor Branca' } \\
\text { and 'Junko }\end{array}$ & $\begin{array}{l}2.16- \\
2.77(\%)\end{array}$ & $7.7-8.6$ & $\begin{array}{l}1.52- \\
1.88\end{array}$ & $\begin{array}{l}3.0- \\
8.31\end{array}$ & $\begin{array}{l}2.97- \\
3.75\end{array}$ & & $\begin{array}{l}\text { Ribeiro and } \\
\text { de Freitas } \\
(2020)\end{array}$ \\
\hline $\begin{array}{l}\text { Carpina } \\
\text { Pernambuco } \\
\text { State PE }\end{array}$ & $\begin{array}{l}7^{\circ} 51^{\prime} 04^{\prime \prime} \\
\mathrm{S}, \\
35^{\circ} 14^{\prime} 27^{\prime \prime} \\
\mathrm{W}, \\
178 \mathrm{~m} \text { asl }\end{array}$ & $\begin{array}{l}18 \text { genotypes } \\
\text { PL26 to PL45 }\end{array}$ & $\begin{array}{l}750- \\
1678\end{array}$ & $\begin{array}{l}6.66- \\
11.46\end{array}$ & $\begin{array}{l}0.96- \\
1.97\end{array}$ & $\begin{array}{l}3.79- \\
7.06\end{array}$ & $\begin{array}{l}2.9- \\
3.5\end{array}$ & & $\begin{array}{l}\text { Maciel et } \\
\text { al. (2010) }\end{array}$ \\
\hline $\begin{array}{l}\text { Limoeiro do } \\
\text { Norte Country, } \\
\text { Ceará State CE }\end{array}$ & & $\begin{array}{l}38 \text { clones } \\
\text { and } \\
\text { Sertaneja, } \\
\text { Flor branca, } \\
\text { Camta 40.2, } \\
\text { Monami, } \\
\text { Okinawa, } \\
\text { Mineira, } \\
\text { Barbados }\end{array}$ & $\begin{array}{l}501- \\
1855\end{array}$ & $\begin{array}{l}5.7- \\
11.1\end{array}$ & $\begin{array}{l}0.53- \\
1.52\end{array}$ & $\begin{array}{l}4.32- \\
11.94\end{array}$ & $\begin{array}{l}3.31- \\
3.91\end{array}$ & & $\begin{array}{l}\text { Moura et } \\
\text { al. (2007) }\end{array}$ \\
\hline $\begin{array}{l}\text { Limoeiro do } \\
\text { Norte - Ceará } \\
\text { State CE, }\end{array}$ & & $\begin{array}{l}\text { BV1, BV2, } \\
\text { BV3 e C6P3 }\end{array}$ & $\begin{array}{l}732- \\
1087\end{array}$ & $\begin{array}{l}6.32- \\
7.48\end{array}$ & $\begin{array}{l}0.97- \\
1.02\end{array}$ & $\begin{array}{l}6.49- \\
7.63\end{array}$ & $\begin{array}{l}3.21- \\
3.59\end{array}$ & & $\begin{array}{l}\text { Silva } \\
\text { Freitas et } \\
\text { al. (2012) }\end{array}$ \\
\hline $\begin{array}{l}\text { Acaraú, } \\
\text { Caucaia, } \\
\text { Maranguape, } \\
\text { Paraipaba, } \\
\text { Uruburetama } \\
\text { and Itapajé - } \\
\text { Ceará State CE }\end{array}$ & & $\begin{array}{l}\text { Samples } \\
\text { A1, A2, A3, } \\
\text { A4, A5, A6, } \\
\text { A7 }\end{array}$ & $\begin{array}{l}968- \\
1349\end{array}$ & $4.7-5.3$ & $\begin{array}{l}0.86- \\
0.99\end{array}$ & $\begin{array}{l}5.33- \\
5.74\end{array}$ & $\begin{array}{l}3.39- \\
3.59\end{array}$ & & $\begin{array}{l}\text { Santos et } \\
\text { al. (2012) }\end{array}$ \\
\hline $\begin{array}{l}\text { Pacajús, Ceará } \\
\text { State CE }\end{array}$ & & $\begin{array}{l}\text { Flor Branca, } \\
\text { BRS366 } \\
\text { and Florida } \\
\text { Sweet }\end{array}$ & $\begin{array}{l}863- \\
1364\end{array}$ & $\begin{array}{l}6.63 \\
9.46\end{array}$ & $\begin{array}{l}0.61- \\
1.06\end{array}$ & $\begin{array}{l}5.98- \\
15.42\end{array}$ & $\begin{array}{l}3.18- \\
3.68\end{array}$ & $1562-2631$ & $\begin{array}{l}\text { Souza et } \\
\text { al. (2014) }\end{array}$ \\
\hline
\end{tabular}




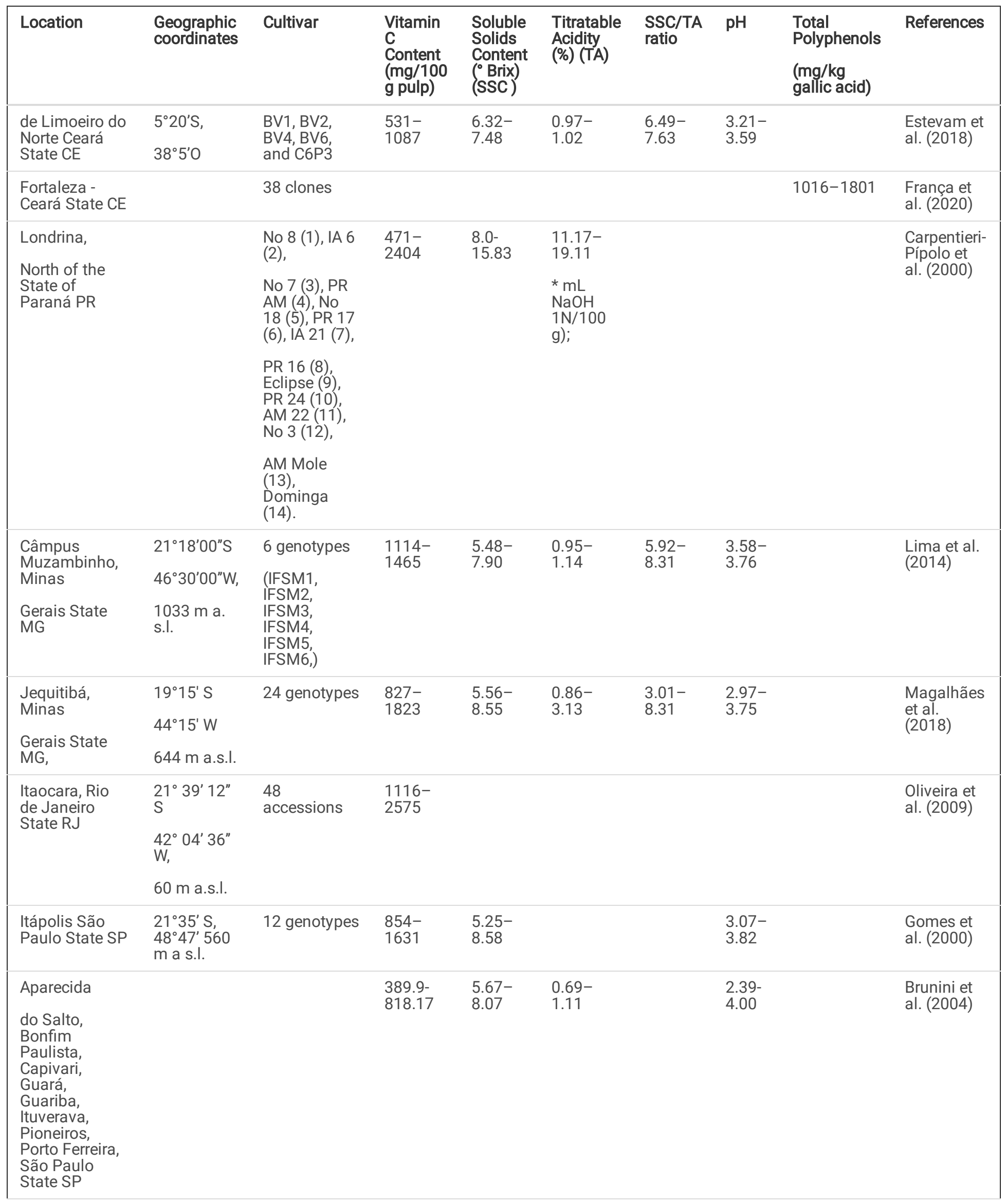




\begin{tabular}{|c|c|c|c|c|c|c|c|c|c|}
\hline Location & $\begin{array}{l}\text { Geographic } \\
\text { coordinates }\end{array}$ & Cultivar & $\begin{array}{l}\text { Vitamin } \\
\text { C } \\
\text { Content } \\
\text { (mg/100 } \\
\text { g pulp) }\end{array}$ & $\begin{array}{l}\text { Soluble } \\
\text { Solids } \\
\text { Content } \\
\text { (Brix) } \\
\text { (SSC) }\end{array}$ & $\begin{array}{l}\text { Titratable } \\
\text { Acidity } \\
\text { (\%) (TA) }\end{array}$ & $\begin{array}{l}\text { SSC/TA } \\
\text { ratio }\end{array}$ & $\mathrm{pH}$ & $\begin{array}{l}\text { Total } \\
\text { Polyphenols } \\
\text { (mg/kg } \\
\text { gallic acid) }\end{array}$ & References \\
\hline \multirow{3}{*}{$\begin{array}{l}\text { Jaboticabal, } \\
\text { São Paulo } \\
\text { State SP }\end{array}$} & & & \multirow[t]{3}{*}{$\begin{array}{l}576- \\
1141\end{array}$} & \multirow[t]{3}{*}{$\begin{array}{l}5.25- \\
7.75\end{array}$} & \multirow[t]{3}{*}{$\begin{array}{l}0.35- \\
1.15\end{array}$} & \multirow[t]{3}{*}{$\begin{array}{l}5.44- \\
19.39\end{array}$} & & & \multirow{3}{*}{$\begin{array}{l}\text { Cavalcante } \\
\text { et al. } \\
\text { (2007) }\end{array}$} \\
\hline & & $\begin{array}{l}\text { Acer-2, Acer- } \\
\text { 3, Acer-4, } \\
\text { Acer-5, Acer- } \\
\text { 6, Acer7, } \\
\text { Acer-8, Acer- } \\
\text { 9, Acer-10, } \\
\text { Acer-11, Acer- } \\
\text { 12, }\end{array}$ & & & & & & & \\
\hline & & $\begin{array}{l}\text { Acer-13, Acer- } \\
\text { 14, Acer-15 } \\
\text { and Acer-16 }\end{array}$ & & & & & & & \\
\hline \multirow{2}{*}{$\begin{array}{l}\text { Junqueirópolis, } \\
\text { San Paulo } \\
\text { State SP }\end{array}$} & $21^{\circ} 18^{\prime} 00^{\prime \prime} \mathrm{S}$ & \multirow[t]{2}{*}{ Olivier } & \multirow[t]{2}{*}{810} & \multirow[t]{2}{*}{7.58} & \multirow[t]{2}{*}{3.15} & \multirow[t]{2}{*}{2.41} & \multirow[t]{2}{*}{3.7} & & \multirow{2}{*}{$\begin{array}{l}\text { Adriano } \\
\text { and } \\
\text { Evangelista } \\
(2011)\end{array}$} \\
\hline & $\begin{array}{l}51^{\circ} 15^{\prime} 00^{\prime \prime} \\
\text { W } 420 \mathrm{~m} \\
\text { a.s.l. }\end{array}$ & & & & & & & & \\
\hline \multirow{8}{*}{$\begin{array}{l}\text { Adamantina } \\
\text { San Paulo } \\
\text { State SP }\end{array}$} & & $\begin{array}{l}\text { Olivier, } \\
\text { Okinawa, }\end{array}$ & \multirow[t]{8}{*}{$\begin{array}{l}1135- \\
2580\end{array}$} & \multirow[t]{8}{*}{$7.3-9.5$} & \multirow[t]{8}{*}{$\begin{array}{l}0.76- \\
1.45\end{array}$} & \multirow[t]{8}{*}{$\begin{array}{l}5.8- \\
10.49\end{array}$} & \multirow[t]{8}{*}{$\begin{array}{l}3.4- \\
3.7\end{array}$} & & \multirow{8}{*}{$\begin{array}{l}\text { Nasser and } \\
\text { Zonta } \\
\text { (2014) }\end{array}$} \\
\hline & $51^{\circ} 08^{\circ} \mathrm{W}$ & Waldy - CATI & & & & & & & \\
\hline & 400 m a.s.I. & 30 & & & & & & & \\
\hline & & Mirandópolis, & & & & & & & \\
\hline & & $\begin{array}{l}\text { BRS } 235 \text { - } \\
\text { Apodi }\end{array}$ & & & & & & & \\
\hline & & $\begin{array}{l}\text { BRS } 236 \text { - } \\
\text { Cereja, }\end{array}$ & & & & & & & \\
\hline & & $\begin{array}{l}\text { BRS } 237 \text { - } \\
\text { Roxinha, }\end{array}$ & & & & & & & \\
\hline & & $\begin{array}{l}\text { BRS } 238 \text { - } \\
\text { Frutacor }\end{array}$ & & & & & & & \\
\hline \multirow{4}{*}{$\begin{array}{l}\text { Adamantina, } \\
\text { San Paulo } \\
\text { State SP }\end{array}$} & $21^{\circ} 40^{\circ} \mathrm{S}$ & $\begin{array}{l}\text { BRS } 235 \text { - } \\
\text { Apodi, }\end{array}$ & \multirow[t]{4}{*}{$\begin{array}{l}825- \\
2332\end{array}$} & \multirow[t]{4}{*}{$\begin{array}{l}6.66- \\
8.36\end{array}$} & \multirow[t]{4}{*}{$\begin{array}{l}0.88- \\
1.64\end{array}$} & & \multirow[t]{4}{*}{$\begin{array}{l}2.85- \\
3.43\end{array}$} & \multirow[t]{4}{*}{$914-2428$} & \multirow{4}{*}{$\begin{array}{l}\text { Mariano- } \\
\text { Nasser et } \\
\text { al. (2017) }\end{array}$} \\
\hline & $51^{\circ} 08^{`} \mathrm{~W}$ & Mirandópolis, & & & & & & & \\
\hline & $400 \mathrm{~m}$ a.s.l. & $\begin{array}{l}\text { Waldy - CATI } \\
\text { 30, BRS } 238 \text { - } \\
\text { Frutacor, } \\
\text { Okinawa, }\end{array}$ & & & & & & & \\
\hline & & $\begin{array}{l}\text { BRS } 236 \text { - } \\
\text { Cereja, Olivier } \\
\text { and BRS 237- } \\
\text { Roxinha }\end{array}$ & & & & & & & \\
\hline \multirow[t]{2}{*}{ San Paulo } & $\begin{array}{l}22^{\circ} 46^{\prime} \mathrm{S} \\
48^{\circ} 34^{\prime} \mathrm{W}^{\prime}\end{array}$ & Olivier & 1676 & 6.57 & 0.61 & 10.73 & 3.58 & & $\begin{array}{l}\text { Corrêa et } \\
\text { al. (2017) }\end{array}$ \\
\hline & 740 m a.s.I. & & & & & & & & \\
\hline
\end{tabular}

No studies have reported the biochemical and morphological caracterization of acerola phenotypes for the region of Western Paraná, the area where the commercial production of acerola is expanding in Brazil.

In this context, it is of great importance to assess the variability in fruit quality among different individuals of acerola to aid pre-breeding programs of non-domesticated species (Moura et al. 2013; Almeida Júnior et al. 2014; Silva et al. 2017). Hence, the objectives of this study were to: (1) characterize 103 acerola phenotypes using morphological and biochemical parameters; (2) select the best phenotypes suitable for the pharmaceutical industry or as a foodstuff supplement that can be used in future breeding programs for the subtropical Western Paraná region. 


\section{Material And Methods}

\subsection{Sampling}

Completely ripe acerola fruits were harvested from 103 trees (phenotypes) located in different gardens of the Marechal Cândido Rondon city, in Western Paraná State, Brazil, located at a latitude of $24^{\circ} 33^{\prime} 23.26$ "S and a longitude of $54^{\circ} 3^{\prime} 28.33^{\prime \prime} \mathrm{W}, 420$ meters above sea level, during the months of October - December 2019. The meterological data during the sampling period was recorded. Rainfall ranged from 25 $\mathrm{mm}$, in October, to $248 \mathrm{~mm}$ in December (Fig. 2). The average temperature varied from $23.3^{\circ} \mathrm{C}$ to $25.9^{\circ} \mathrm{C}$; the maximum temperature ranged from $35^{\circ} \mathrm{C}$, in December, to $39.9^{\circ} \mathrm{C}$ in October (Fig. 2).

The fruits were harvested randomly by hand at the full ripening stage, from all parts of the canopy, thus obtaining a representative sample from each tree. Approximately one kilogram of fruit was harvested from each of 103 trees, each one called a phenotype and numbered from 1 to 103 .

The freshly harvested fruits were immediately taken to the Food Technology Laboratory at Western Paraná State University (Unioeste) where they were analyzed physically and chemically.

\subsection{Fruit size, weight, color parameters and pulp yield}

For each phenotype, four repetitions, composed of ten fruits, were used to determine fruit parameters. A digital caliper was used to measure the length between the point of peduncle insertion and the apex of the fruit (longitudinal diameter) and the the largest length measured perpendicularly to the peduncle (transverse diameter).

The fresh weight of the fruits was also determined on a precision analytical balance and results are expressed in grams (g). The volume of the fruits was estimated by the water displacement method, based on immersing the fruits in a known volume of water in a graduated cylinder and determining the difference between the final and initial volume of water. For these two analyses, four repetitions of five fruits each were used. The fruit volume is experessed in $\mathrm{cm}^{3}$.

The same fruits were analyzed for color parameters using a colorimeter (Konica Minolta brand, model Sensy CR 400, Osaka, Japan). Color is expressed using the rectangular coordinate system $L^{*} a^{*} b *$, according to the Commission Internationale de E'clairage (CIE 1986), where $L^{*}=$ percentage of the luminosity values $\left(0 \%=\right.$ black and $100 \%=$ white), $a^{*}=$ red $(+)$ or green $(-)$ and $b^{*}=$ yellow $(+)$ or blue $(-)$ (McGuire 1992). Color measurements were carried out by measuring the color reading twice per fruit, in opposite regions, to avoid the influence of sun exposure on the fruit (Viúda-Martos et al. 2010; Adriano et al. 2011; Mondragón-Cortez et al. 2013; Mariano-Nasser et al. 2017).

Finally, the fruits were depulped and the seeds from each repetition were weighed to determine the pulp yield, expressed as percentage for each phenotype. The pulp was stored in small plastic bags for later use in chemical analysis and kept in a freezer at a temperature of $-10^{\circ} \mathrm{C}$ until the time of analysis. The data are expressed as means \pm standard error (Table S.1 and Table S.2).

\subsection{Biochemical parameters: soluble solids, $\mathrm{pH}$, titratable acidity, vitamin $\mathrm{C}$ and polyphenols}

Biochemical parameters were determined on three replicates of five fruits from each phenotype. Soluble solids content (SSC) was determined using a digital refractometer (MA871 Milwaukee, WI, USA) with automatic temperature compensation as described by AOAC (2005). The results are expressed as ${ }^{\circ} \mathrm{Brix}$ (concentration of sucrose $\mathrm{w} / \mathrm{w}$ ). The ratio between soluble solids and titratable acidity (SSC/TA) was also calculated.

The $\mathrm{pH}$ was determined on the stored pulp using an automatic pHmeter (Labmeter® PHS-3B, São Paulo- Brazil) as recommended by AOAC (2005).

Titratable acidity (TA) was determined with phenolphthalene (Ali 2008) and the results are expressed in grams of malic acid per 100 grams of pulp, carried out according to the methodology proposed by the Adolfo Lutz Institute (Lutz 1985). The vitamin C (ascorbic acid) content was determined by titration (Tillmans modified method) based on the reduction of 2,6-dichloro-phenol-indophenol by ascorbic acid (Benassi and Antunes 1988). One gram of pulp was diluted in $100 \mathrm{~mL}$ of $0.5 \%$ oxalic acid and homogenized. Then, $5 \mathrm{~mL}$ of this solution was diluted

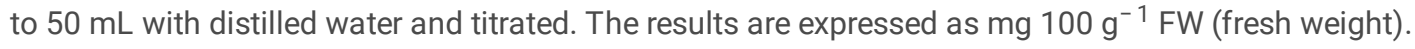

The content of total phenolic compounds was determined according to the conventional Folin-Ciocalteu spectrophotometric procedure developed by Georgé et al. (2005). Extracts were added to $1 \mathrm{~mL}$ Folin Ciocalteu reagent (1 N), $2 \mathrm{~mL} \mathrm{Na} \mathrm{CO}_{3}$ at $20 \%$ and $2 \mathrm{~mL}$ of distilled 
water and absorbance was monitored at $700 \mathrm{~nm}$. Results were calculated from a standard curve of $98 \%$ gallic acid (0-50 $\mu \mathrm{g})$ and are expressed as gallic acid equivalents (GAE) $\mathrm{mg} 100 \mathrm{~g}^{-1} \mathrm{FW}$.

The analyses of $\mathrm{pH}$, titratable acidity, vitamin $\mathrm{C}$ and total phenolics were performed in triplicate and data are expressed as means \pm standard error (Table S.2).

\subsection{Statistical data analysis}

To study the relevant data of the acerola phenotypes, the Box plot data analysis method was applied, using SigmaPlotß8.0, which provides an effective summary of a potentially large amount of data. In the box plot method, the input data set is split into quartiles. A box plot has a minimum value, lower quartile (10th ), median, upper quartile (90th ), and maximum value. The box plot goes from the lower quartile to the upper quartile. The difference between the upper quartile and the lower quartile is the length of the box. Inside the box of the box plot, one horizontal line is drawn, which is the median of the dataset. On the outside of the box of the box plot, two more horizontal lines are drawn, one horizontal near upper quartile is called the upper whisker and another line near the lower quartile is called the lower whisker. The end points of the whiskers are typically defined as the most extreme data points (Streit and Gehlenborg 2014).

The Hierarchical Cluster Analysis (HCA) was performed using the chemical and physical parameters of the phenotypes as input variables. Since the variables had different scales and units, PCA was calculated on autoscaled variables. Autoscaling consists in transforming each variable by subtracting its average value and then dividing it by its standard deviation. This transformation allows the data to be translated to the origin of the reference system since each variable will have an average value equal to zero, and this also makes the variability of each variable equally important (Wise and Gallagher 1996). The primary goal of HCA is to display the data in such a way so as to emphasize their natural clusters and patterns in a two-dimensional space. The results, qualitative in nature, are usually presented as a dendrogram, making it possible to visualize the clusters and correlations among samples or variables. In HCA, the Euclidean distances between samples or variables are calculated and transformed into a similarity matrix whose elements are similarity indexes ranging from 0 to 1 ; a smaller distance means a larger index and therefore, greater similarity (Granato et al. 2010). For hierarchical cluster analysis the dataset was treated with the Ward's method of linkage with squared Euclidean distance as a measure of similarity. The quality of the dendrogram obtained after HCA was evaluated by the co-phenetic correlation coefficient, which represents a statistical criterion widely used, selecting the hierarchical clustering method when there is no prior knowledge of the pattern of clustering (Matta et al. 2015).

Principal component analysis (PCA) was also performed on the same input variables used for HCA analysis to explore the variability among samples and to detect the most discriminating coordinates (principal components, PCs). PCA summarizes the information contained in the data matrix in fewer independent PCs, obtained as linear combinations of the original variables, lying in the direction of maximum variance (Portarena et al. 2019). The data were statistically evaluated using r.

\section{Results And Discussion}

\subsection{Morphological parameters}

The acerola fruits from the 103 phenotypes presented a large variability in terms of fresh weight, fruit volume, pulp yield, size and color parameters (Fig. 3, Table S.1).

Fruit fresh weight varied from $1.53 \mathrm{~g}$ to $8.85 \mathrm{~g}$ with a mean value of $4.6 \mathrm{~g}$ and a median of $4.55 \mathrm{~g}$ (Fig. 3, Table A.1).

In $66 \%$ of the phenotypes, the mean fruit mass was over $4 \mathrm{~g}$, the limit required by the industry (Semensato and Pereira 2000) (Table S.1). The range was within that reported in the literature, even though minimum values were slightly lower (Table S.3).

Fruit volume varied from $2.2 \mathrm{~cm}^{3}$ to $9.40 \mathrm{~cm}^{3}$ with a mean value of $4.85 \mathrm{~cm}^{3}$ and a median value of $4.70 \mathrm{~cm}^{3}$ (Fig. 3 , Table S.1). The range was within that reported by Magalhães et al. (2018) even though maximum values were higher (Table S.3).

Pulp yield ranged from $57.2-90.1 \%$ with a mean value of $76.05 \%$ and a median of $76.14 \%$ (Fig. 3 and Table S.1). These values are within the range reported by Brunini et al. (2004), Magalhães et al. (2018) and Maciel et al. (2010), but with higher maximum values than those recorded by Carpentieri - Pipolo et al. (2000) in Northern Paraná State and in other areas of Brazil (Cavalcante et al. 2007) (Table S.3); they were even higher than the range recorded by Gomes et al. (2000). Table S.1 shows that 6.8\% of the phenotypes had a pulp yield of around $84 \%$, which is a good amount for the pulp processing industry (Magalhãe et al. 2018). According to these authors, this is an essential quality characteristic of acerola destined for processing because it directly affects the cost/benefit ratio. 
The longitudinal diameter of the fruit ranged from 13.0 to $22.7 \mathrm{~mm}$ with a mean value of $17.5 \mathrm{~mm}$ and a median value of $17.8 \mathrm{~mm}$. The transverse diameter ranged from 14.3 to $27.8 \mathrm{~mm}$ with a mean value of $20.4 \mathrm{~mm}$ and a median value of $20.5 \mathrm{~mm}$ (Fig. 3 and Table S.1). These ranges were slightly greater than those reported by Carpentieri-Pípolo et al. (2000) who reported a mean longitudinal diameter between 9.40 and $18.60 \mathrm{~mm}$ and a transverse diameter between 8.53 and $17.40 \mathrm{~mm}$, but they were within the ranges reported by others (Table S.3). Only $2 \%$ of the phenotypes had transverse diameters less than $15 \mathrm{~mm}$ (numbers 67 and 75), the value which, according to Semensato and Pereira (2000), is recommended for industrial use (Table S.1). The analysis of longitudinal and transverse diameters showed that the fruit is wider, than long. According to Gonzaga Neto et al. (1999), the larger the fruit, the easier and quicker is harvesting because there is less labor involved and, consequently, production costs are reduced, and the fruit is more attractive for consumption (Magalhãe et al. 2018).

The colors of the acerola phenotypes varied greatly. The brightness index $L$ ranged from 19.4 to 55.9 with a mean value of 31.2 and a median value of 30.4 (Fig. 3, Table S.1). Similar high L values were observed by Brunini et al. (2004) and Mariano-Nasser et al. (2017), while the lower values were lower than those reported in the literature (Table S.3). Looking at the box plot, it can be seen that the L parameter of half of the phenotypes was over the median value, and the other half below, which is in agreement with data reported by Godoy et al. (2008) (Fig. 3).

Parameter color a, corresponding to red, ranged from 11.3 to 46.6 with mean value of 28.3 and a median value of 26.6 (Fig. 3 and Table S.1), which was a wider range with respect to those reported by Figueiredo Neto et al. (2014) and Mariano-Nasser et al. (2017) (Table S.3).

Parameter color b, corresponding to yellow, showed an even wider range, ranging from 3.0 to 48.9 , with a mean value of 14.9 and a median value of 11.9; both the mean and the minimum values were within the ranges reported in the literature (Table S.3), but the maximum values were much higher (Fig. 3 and Table S.1).

The comparison of the two parameters color a and color b showed that yellow is predominant with respect to red, in agreement Godoy et al. (2008), except for two phenotypes (numbers 15 and 102) in which red is dominant, as indicated by the round symbols above the box (Fig. 3 , Table S.1). With the exception of phenotypes numbers 15 and 102, all the phenotypes were within the specifications required by the pharmaceutical industry that prefers orange colored acerola (Semesato and Pereira 2000), discarding purple and yellow ones (Lima et al., 2014); in fact, in agreement with Loápez (1963), fruits are harvested when they begin to turn a pinkish-orange or light-red color.

\subsection{Chemical characters of acerola}

The acerola fruits had a high variability in terms of vitamin $\mathrm{C}$ content, soluble solids, titratable acidity, $\mathrm{pH}$, soluble solids/ titratable acidity ratio and total polyphenols (Fig. 4, Table S.2).

The fruit soluble solids content (SSC) varied from $6.4^{\circ}$ Brix to $12.1^{\circ}$ Brix, with a mean value of 8.7 and a median of 8.5 , in agreement with Musser et al. (2004), who reported a range of $5-12^{\circ}$ Brix in relation to different edaphoclimatic conditions in Brazil (Fig. 4 ). The variations in the present study were similar to those described by Moura et al. (2007), Maciel et al. (2010), Figueiredo Neto et al. (2014), Estevam et al. (2018) and Carpentieri-Pípolo et al. (2000) (Table 1). These last authors reported the highest SSC values with means between 8.0 and 15.8 ${ }^{\circ}$ Brix in acerola accessions from the Northeastern region of Paraná. High values of SSC are important for consumption as fresh or processed fruit. Loápez (1963) showed the SSC increased as the fruit ripened, or as the season progressed and that it can be used as a ripening index. According to Alves et al. (1995) normal maturation occurs when fruits are harvested with at least $6.5 \%$ soluble solids. All the phenotypes had values over this threshold except for number 16, which was slightly lower (6.38 ${ }^{\circ}$ Brix) (Table S.2).

The $\mathrm{pH}$ varied from 2.72 to 4.36 with a mean value of 3.43 and a median value of 3.44 (Fig. 4; Table S.2). This range of variation is wider than that found in the literature (Table 1).

It is noteworthy that, except for number 14, all phenotypes are in accordance with the specifications for fruit quality pulp determined by MAPA (Ministério da Agricultura Pecuária e Abastecimento), which requires at least $5.5^{\circ} \mathrm{Brix}$ of soluble solids and a pH of 2.8 (Brasil 2000 ) (Table A.2). In fact, the $\mathrm{pH}$ is a very important parameter influencing the quality and safety of the fruit because it gives an indication of its storage potential, (which is indicated by the development of acidity) and its assessment is very important in the industrial processing of fruit pulp.

Titratable acidity (TA) varied from $0.4-3.8 \%$, with a mean value of 3.07 and a median value of 3.20\% (Fig. 4; Table S.2). The lower values are similar to those reported in the literature, while the upper values are slightly higher than those described by Magalhães et al. (2018), who reported values between 0.86 and $3.13 \%$ (Table 1 ). 
According to Nascimento et al. (2018), high TA is important for fruit industrial processing, as it reduces the need to add artificial acidic substances, although this is not a limiting factor in genotype selection where other fruit quality parameters are satisfactory. On the other hand, low titratable acidity is relevant for consumption as fresh fruit (Seymour and Tucker 1993; Godoy et al. 2008).

The ratio between soluble solids and titratable acidity ranged considerably from 1.86 to 18.62 , with a mean of 2.95 and a median of 2.70 (Fig. 4 and Table S.2). This wide range of variation was closer to those described by Cavalcante et al. (2007) (5.44-19.39) and Souza de et al. (2014) (5.98-15.42). The minimum values were slightly lower than those reported in the literature, but higher than those reported by Semensato and Pereira (2000) (Table 1). The ratio between SSC and titratable acidity indicates the degree of balance between the sugar and organic acid content of the fruit, which is directly related to fruit flavor (Chitarra and Chitarra 2005). Therefore, it is an important variable in the selection of table varieties, even for acerola because the higher is the ratio, the sweeter is the fruit (Estevam et al. 2018; Magalhae et al. 2018).

The vitamin C content of the 103 phenotypes varied from $425 \mathrm{mg}$ to $2625 \mathrm{mg} / 100 \mathrm{~g}$ pulp, with a mean value of $1240 \mathrm{mg} / 100 \mathrm{~g} \mathrm{pulp}$ and a median value of $1260 \mathrm{mg} / 100 \mathrm{~g}$ pulp (Fig. 4 and Table S.2). In fact, $75.7 \%$ showed a mean content over the minimum $(800 \mathrm{mg} / 100 \mathrm{~g})$ recommended for breeding programs by Brazilian law (Brasil 2000; Godoy et al., 2008) (Fig. 4 and Table S.2). Moreover, $52.4 \%$ of the phenotypes reached a mean content of vitamin $\mathrm{C}$ above the threshold of $1200 \mathrm{mg} / 100 \mathrm{~g}$ pulp recommended by the Instituto Brasileiro de Frutas (1995) for industrial use and 68.9\% exceeded the limit of 1000 required for export to Europe and Japan (Table S.2) (Maciel et al. 2010). Phenotypes numbers $14,29,4,66,60,37$ and 99 had the highest vitamin C content, ranging from 2025 to $2625 \mathrm{mg} / 100 \mathrm{~g}$ pulp (Fig. 4, Table S.2).

Our results gave the highest range of vitamin $\mathrm{C}$ content with respect to those reported in the literature, except for those reported by Figueiredo Neto et al. (2014) in Petrolina (Pernambuco State) in two commercial cultivars (Okinawa and Sertaneja), with a maximum value of $3597 \mathrm{mg} / 100 \mathrm{~g}$ pulp (Table 1). However, our results are close to those reported by Carpentieri-Pípolo et al. (2000), who analyzed fourteen genotypes of acerola in Northern Paraná State, obtaining values between 471 and $2404 \mathrm{mg} / 100 \mathrm{~g}$ pulp in ripe fruits (Table 1); by Oliveira et al. (2009), who analyzed 48 accessions in Itaocara (Rio de Janeiro State), obtaining values between 1116 and $2575 \mathrm{mg} / 100 \mathrm{~g}$ pulp in ripe fruits and by Nasser and Zonta (2014) and Mariano-Nasser et al. (2017), who obtained values between 825 and $2580 \mathrm{mg} / 100 \mathrm{~g}$ pulp in Adamantina (San Paulo State) (Table 1).

The polyphenol content in the acerola fruits was also quite variable, ranging from $84 \mathrm{mg} / \mathrm{kg}$ to $3196 \mathrm{mg} / \mathrm{kg}$ with a mean value of 1397 $\mathrm{mg} / \mathrm{kg}$, a median value of $1367 \mathrm{mg} / \mathrm{kg}$ (Fig. 4 and Table S.2). Phenotype number 40 gave an exceptionally high value, equal to 3196 $\mathrm{mg} / \mathrm{kg}$. However, nearly 50\% of the phenotypes had a polyphenol content ranging from 1173 to $1704 \mathrm{mg}$ (Fig. 4 and Table S.2). Moreover, as vitamin $\mathrm{C}$ and polyphenol contents are of great interest to the pharmaceutical industry, these phenotypes have potential for use as clonal varieties. Although polyphenols are important in this fruit, there have been very few studies in acerola (Table 1). In fact, they are an excellent source of antioxidant activity and contribute to fruit color and flavor quality, producing astringency and bitterness (Vendramini and Trugo 2000). Souza et al. (2014) found values from 1562 to $2631 \mathrm{mg}$ of gallic acid $100 \mathrm{~g}^{-1}$ of pulp; Mariano-Nasser et al. (2017) reported values from 914 to $2428 \mathrm{mg}$ of gallic acid $100 \mathrm{~g}^{-1}$ of pulp and França et al. (2020) reported values from 1016 to $1801 \mathrm{mg}$ of gallic acid $100 \mathrm{~g}^{-1}$ of pulp. However, the range of variation in these three studies was lower than the current study.

We postulate that the physical and biochemical variations among the 103 phenotypes are all due to intrinsic genetic differences (Nakazone et al., 1966; Gomes et al., 2000; Hanamura et al., 2008; Maciel et al., 2010; Mariano-Nasser et al., 2017; Estevam et al., 2018) rather than to environmental, ripening and storage conditions since all samples were collected in the same area of the Marechal Cândido Rondon city, at the same maturation and storage conditions (see Sect. 2.1).

\subsection{Correlations among variables}

To examine the relationships among the fruit quality parameters, Pearson's correlation analysis was performed. The results are shown in Fig. 5.

Color traits showed the highest number of correlations (Fig. 5). In particular, L, a and b were positively correlated with fruit size, but were negatively correlated with percentage of pulp, titratable acidity and $\mathrm{pH}$ ( $\mathrm{r}=-0.55 \mathrm{for} \mathrm{b}$ color). Color is one of the most important factors in consumers' decisions and hence affects the price of the fruit. pH influences the color of anthocyanins and also their stability and enzymatic coloration is favored by lower pH values (Oliveira et al. 2012; Wahyuningsih et al. 2017).

There were no significant correlations between vitamin $\mathrm{C}$ and fruit size (Fig. 5). pH and SSC were negatively correlated with longitudinal diameter $(r=-0.45)$, transverse diameter $(r=-0.46)$, fruit weight and fruit volume $(r=-0.43$ and -0.44 respectively), so the larger the fruit size, the lower were the pH and SSC, probably due to a dilution effect (Baldicchi et al. 2015; Famiani et al. 2020).

Page $10 / 22$ 
Fruit size, in terms of longitudinal and transversal diameter, was negatively correlated with pH and SSC. Furthermore, vitamin $\mathrm{C}$ and polyphenols were low, but significantly $(p<0.05)$ correlated $(r=0.24)$. This correlation, also reported by França et al. $(2020)$, can be explained as the fruit response to progressive oxidative stress. In fact, with ripening there is a reduction in oxygen scavenging enzyme activities and an increase in membrane lipid peroxidation, indicating that acerola ripening is characterized by progressive oxidative stress (Prakash and Baskaran 2018). Moreover, enzymes such as ascorbate oxidase or peroxidase may accelerate ascorbic acid oxidation during ripening and therefore lead to its reduction (França et al. 2020).

In a recent review, Prakash and Baskaran (2018) also reported that with ripening, vitamin $\mathrm{C}$ decreases and phenols degrade; the decrease in total vitamin $\mathrm{C}$ and total soluble phenol content reduction determine lower total antioxidant activity. Even if the reduction in vitamin $\mathrm{C}$ has a much more significant influence on acerola antioxidant capacity than phenolic compounds (Xu et al. 2020), the high capacity of ripe acerola fruits to sequester free radicals is due to their high content of vitamin C, in agreement with França et al. (2020)..

Although vitamin $\mathrm{C}$ content had a wide range of variation in the 103 phenotypes, there was no correlation with other fruit quality parameters (Fig. 5).

\subsection{Classification of acerola phenotypes}

The heat map row and column dendrogram, based on hierarchical clustering (Euclidean distances and Ward's method) classification provided a framework for exploring how the parameters may explain phenotypical differences among samples. It revealed information about how the samples and variables cluster together and provided insights into potential sample biases.

The results revealed two distinct sample and variable clusters (Fig. 6).

As observed from the color gradient (red = low intensity; yellow = high intensity), Ward's linkage revealed that fruit size and color parameters were the main sample clustering factors. Biochemical parameters presented a mixture of high and low values in both clusters.

Cluster 1 encompassed 37 phenotypes. It was mostly characterized by relatively high intensity of color parameters and fruit size. Moreover, two sub-groups could be traced. They differed based on color intensity and exhibited a pattern of divergence with weight and size parameters. Cluster 2 contained the largest number of samples (66). It was mainly characterized by low intensity color parameters that mostly overlapped with small fruit size and weight. It included a great variability in the biochemical compounds with many samples having a high content of vitamin C, polyphenols and SSC. Samples from Cluster 2 were the most similar in terms of weight, volume and color.

Biochemical parameters presented no clear clustering and were mixed inside each subgroup. However, the lowest values of pH and titratable acidity were correlated with the sub-cluster with high intensity color parameters, confirming the negative correlation between $\mathrm{pH}$ and color parameters (Fig. 5). The soluble solids/titratable acidity ratio displayed relatively stable values in all the clusters, except for sample 1 that had the highest ratio (Table S.2).

The co-phenetic correlation coefficient calculated for the two main clusters was 0.7101 , indicating the adequacy of the clustering method (Rohlf and Fisher 1968).

PCA was performed on the complete dataset to explore the variability among samples by combining all physical and biochemical parameters and to quantify the contribution of each parameter in determining the two main clusters obtained by HCA. The scatter plot shown in Fig. 7 shows the geometrical distances among the 103 phenotypes within the bi-dimensional plane defined by the PC1 and PC2 variables. The two sample groups, differing by colors, corresponding to the clusters defined by HCA.

Almost $55 \%$ of the total variance is explained by the first 2 PCs. The main separation between the two clusters was obtained through PC1. The descriptors contributing the most in $\mathrm{PC} 1$ (35.4\% of the total variance) were fruit size, color parameters and $\mathrm{pH}$, confirming the results of the heat map cluster analysis (Fig. 6). In particular, samples from cluster 1 (red symbols) showed higher values of fruit size and color parameters.

Samples from cluster 2 (blue symbols) basically presented higher values of soluble solids, pH, polyphenols and pulp yield (Fig. 7).

The descriptors contributing the most in PC2 (18.8\% of the total variance) were titratable acidity, and soluble solids/ titratable acidity ratio, the first being positively correlated to vitamin C (Fig. 5).

Wide variability was also observed within each cluster. In particular, according to PCA values, phenotypes from the upper-left position of the graph (Fig. 7) showed the highest content of soluble solids. Phenotypes that gathered negative values of PC1 and PC2 were characterized by the combination of high polyphenols and vitamin $\mathrm{C}$ content.

Page $11 / 22$ 
Cruz et al. (2004) suggested performing crosses between parent accessions with the greatest possible divergence and good performance to increase heterosis and the chance of generating superior individuals; in fact, crosses between divergent phenotypes allows the heterotic effect to be exploited and segregating populations with greater variability in crosses to be obtained (Oliveira et al. 2009; Bianchi et al. 2017). From the industrial point of view, acerola fruits from cluster 2 were the most interesting for their biochemical constituents, even if they had low average fruit size values (Fig. 7, Table S.1, Table S.2).

\subsection{Selection of phenotypes}

This characterization will make it possible to propagate clonal phenotypes with desirable commercial characteristics, and will aid in the selection of useful traits desirable for the development of new, industrial-driven cultivars.

The high performance of phenotypes 99 and 66, belonging to cluster 2, in terms of vitamin $\mathrm{C}$ and pulp yield could be decisive for increasing the vitamin $\mathrm{C}$ content in the progeny. On the other hand, the high pulp yield, fruit size and vitamin $\mathrm{C}$ content in phenotype 37 , belong to cluster 1 , indicated that this phenotype from the two classes of samples could be useful for crosses aimed at improving both the quality and yield of acerola (Fig. 6, Fig. 7, Table S.1, Table S.2, Photo 1).

The suggested combination in breeding programs will produce promising progenies from which superior lines could originate. Anyway, phenotype 37 , due to its superior chemical and physical characteristics, could already be propagated and compared with the most important acerola cultivars (Fig. 5, Fig. 6, Table S.1 and Table S.2).

Four other phenotypes could be selected for their high content of vitamin C: 4, 14, 29 (belonging to cluster 1) and 60 (cluster 2). However, their fruit weight and pulp yield were outside the required parameters (Table S.2).

Therefore, together with the analysis of the performance of the phenotypes, studies on genetic divergence are of great importance for breeding programs because they assess the variability among phenotypes (Silva et al. 2017) and provide information for the identification of mother plants that can be used in crosses with a higher probability of obtaining superior progeny in the segregating generations (Oliveira et al. 2012; Magdales et al. 2018). However, it is not possible to capture the combining ability among parents based solely on their individual performance. The breeder must obtain crosses and evaluate the progenies or use techniques that allow a specific genotype combination to be predicted before the cross is performed (Mihaljevic et al. 2005).

In perspective, the use of DNA markers to estimate genetic distances within the selected individuals will allow acerola phenotypes to be discriminated and the divergent phenotypes should be useful in genetic breeding (Oliveira et al. 2009; Reis et al. 2017).

\section{Conclusions}

The 103 phenotypes of acerola were classified as belonging to two main clusters. Phenotypes from cluster 1 showed higher values of fruit size and color parameters, while phenotypes from cluster 2 basically had higher values of soluble solids, $\mathrm{pH}$, polyphenols, vitamin $\mathrm{C}$ and pulp yield.

The results of the study make it possible to select the best phenotypes suitable for the pharmaceutical industry or as a foodstuff supplement that can be used in future breeding improvement programs for the Western Paraná region. Specifically the high performance of phenotypes 99 and 66, belonging to cluster 2, in terms of vitamin C and pulp yield, and phenotype 37, belonging to cluster 1, with high pulp yield, fruit size and vitamin $\mathrm{C}$ content, could be decisive for increasing vitamin $\mathrm{C}$ content in the progeny. Hence, these phenotypes from the two classes of samples could be useful for crosses aimed at improving both the quality and yield of acerola. Four other phenotypes could be selected for their high content of vitamin C: 4, 14, 29 and 60.

Since genetic improvement depends on the correct choice of the best individuals that will be used as parents, the phenotypes selected will also be characterized from the genetic point of view using DNA markers as the next step in the acerola breeding program at the University of West Paraná.

\section{Declarations}

\section{Funding}

This project was funded by Capes (Coordenação de Aperfeiçoamento de Pessoal de Nível Superior), by the University of Perugia and by "Youth Fund - International Mobility" for the stay granted in Brazil. The research was carried out as part of the activity under the Cooperation Agreement with the University of Perugia and the University of West Paraná - UNIOESTE.

Page $12 / 22$ 


\section{Conflicts of interest}

The authors declare that they have no conflict of interests.

\section{Availability of data and material}

The data are available

\section{Authors' contributions}

VF and SDF: conceptualization and methodology; VF and FD: funding acquisition. VF, SDF, TC, SEC, VJF, SGM: investigation. FD and PS: data and formal analysis. FD and PS: original draft, editing and review. VF, PP, SDF review.

\section{References}

Adriano ELS, Evangelista R M (2011) Qualidade de fruto da aceroleira cv. Olivier em dois estádios de maturação. Revista Brasileira de Fruticultura, 33(spe1), 541-545. https://doi.org/10.1590/S0100-29452011000500073

Ali MM, Woods M, Caravan P, Opina A C, Spiller M, Fettinger J C, Sherry AD (2008) Synthesis and relaxometric studies of a dendrimer-based pH-responsive MRI contrast agent. Chemistry-A European Journal, 14(24), 7250-7258.

Almeida Júnior EB, Chaves LJ, Soares TN (2014) Genetic characterization of a germplasm collection of cagaiteira, a native species of the cerrado. Bragantia 73: 246-252.

Alvares CA, Stape JL, Sentelhas PC, de Moraes Gonçalves JL, Sparovek G (2013) Köppen's climate classification map for Brazil. Meteorologische Zeitschrift, 22(6), 711-728. https://doi.org/10.1127/0941-2948/2013/0507

Alves RE, Chitarra AB, Chitarra MIF (1995) Postharvest physiology of acerola (Malpighia emarginata D.C.) fruits: maturation changes, respiratory activity and refrigerated storage at ambient and modified atmospheres. Acta Hortic. 370, 223-230. DOI:

10.17660/ActaHortic.1995.370.35

AOAC International (2005) Official methods of analysis of AOAC International.

Baldicchi A, Farinelli D, Micheli M, Di Vaio C, Moscatello S, Battistelli A, Walker RP, Famiani F (2015) Analysis of seed growth, fruit growth and composition and PEPCK occurrence in apricot (Prunus armeniaca L.). Scientia Horticulturae n. 186: 38-46. DOI information:

10.1016/j.scienta.2015.01.025

Belwal T, Devkota HP, Hassan HA, Ahluwalia S, Ramadan MF, Mocan A, Atanasov A G (2018) Phytopharmacology of Acerola (Malpighia spp.) and its potential as functional food. Trends in Food Science \& Technology, 74, 99-106. https://doi.org/10.1016/j.tifs.2018.01.014

Benassi MDT, Antunes AJ (1988) A comparison of metaphosphoric and oxalic acids as extractants solutions for the determination of Vitamin C in selected vegetables. Arq. Biol. Tecnol, 507-13.

Bianchi FG, Balbi RV, Pio R, Bruzi AT, Silva DFD (2017) Parents choice and genetic divergence between cambuci fruit tree accessions. Crop Breeding and Applied Biotechnology, 17(3), 214-220. https://doi.org/10.1590/1984-70332017v17n3a33.

Brasil Instrução normativa n01, de 7 de janeiro de 2000 Regulamento técnico geral para flxação dos padrões de identidade e qualidade para polpa de fruta. Diário Oficiai [da] República Federativa do BRASIL, Brasilia, DF, 10 jan. 2000. seção 1, p. 54-55.

Brunini MA, Macedo NB, Coelho CV, Siqueira GFD (2004) Caracterização física e química de acerolas provenientes de diferentes regiões de cultivo. Rev. Bras. Frutic, 486-489. https://doi.org/10.1590/S0100-29452004000300027.

Calgaro M, Brandão B M (2012) A cultura da acerola. - 3. ed. rev. ampl. - Brasília, DF : Embrapa, 2012. 144 p. ; (Coleção Plantar; 69). ISBN 978-85-7035-130-2

Carpentieri-Pípolo V, Destro D, Prete CEC, Gonzales MGN, Popper I, Zanatta S, Silva A (2000) Seleção de genótipos parentais de acerola com base na divergência genética multivariada. Pesquisa Agropecuária Brasileira, 35(8), 1613-1619.

Cavalcante ÍHL, Beckmann MZ, Martins ABG, Campos MCC (2007) Preliminary selection of acerola genotypes in Brazil. Fruits, 62(1), 27-34. 
Caviglione J H, Kiihl LRB, Caramori P H, Oliveira D, Galdino J, Borrozino E, Pugsley L (2000) Cartas climáticas do Estado do Paraná. Londrina: IAPAR, 1 CD-ROM.

Chitarra MIF, Chitarra AB (2005) Pós-colheita de frutas e hortaliças: fisiologia e manuseio. Lavras: UFLA. 785 p.

CIE C (1986) Official recommendations of the International Commission on illumination. Publication CIE No. 15.2.

Corrêa CV, Gouveia AM de S, Martins Bruno N M, Jorge. G, Lanna N de B L, Tavares A E B, Mendonça V Z, Evangelista R M (2017) Influence of ripening stages on physicochemical characteristics of acerola fruits. Revista de Ciências Agrárias, 40(4), 808-813.

https://dx.doi.org/10.19084/RCA17116

Cruz CD, Regazzi A J, Carneiro PCS (2004) Modelos biométricos aplicados ao melhoramento genético. Volume 1. Viçosa, Editora UFV, 1, 480 .

de Ancos B, Fernández-Jalao I, Sánchez-Moreno C (2016) Compuestos Funcionales En Productos De Iv YV Gama. Revista Iberoamericana de Tecnología Postcosecha, 17(2), 130-148.

de Araujo Ferreira R M, Aroucha E MM, de Souza P A, Queiroz R F (2009) Ponto de colheita da acerola visando à produção industrial de polpa. Revista Verde de Agroecologia e Desenvolvimento Sustentável, 4(2), 5.

de Assis SA, Fernandes FP, Martins ABG, de Faria Oliveira OMM (2008) Acerola: importance, culture conditions, production and biochemical aspects. Review of Fruits, 63(2), 93-101. DOI: 10.1051/fruits:2007051

Estevam M I F, de Souza PA, Maracajá P B, Batista EM, Reges B M (2018) Physicochemical of acerola varieties in two stages of maturation. Revista Verde de Agroecologia e Desenvolvimento Sustentável, 13(4), 459-465. DOI: http://dx.doi.org/10.18378/rvads.v13i4.5736

Famiani F, Bonghi C, Chen Z H, Drincovich M F, Farinelli D, Lara MV, Proietti S, Rosati A, Vizzotto G, Walker RP (2020) Stone fruits: growth and nitrogen and organic acid metabolism in the fruits and seeds-A review. Frontiers in Plant Science, $11,1427$.

https://doi.org/10.3389/fpls.2020.572601

Figueiredo Neto A, Reis D, Alves E, Gonçalves E, Anjos FD, Ferreira M (2014) Determinação de vitamina ce avaliação físico-química em três variedades de acerola cultivadas em Petrolina-PE. Nucleus, 11(1), 83-92. doi: 10.3738/1982.2278.987

França L G, Alves Filho E, Ribeiro LB, Evangelista JSB, Silva L.M, de Souza PA, Aragão FAS (2020) Metabolomic profiling of acerola clones according to the ripening stage. Journal of Food Measurement and Characterization, 1-9. https ://doi.org/10.1007/s1169 4-020-00649 -0)

Furlaneto FPB, Nasser MD (2015) Panorama da cultura da acerola no estado de São Paulo. Pesquisa \& Tecnologia, 2015, 12.1: 1-6.

Georgé S, Brat P, Alter P, Amiot MJ (2005) Rapid determination of polyphenols and vitamin C in plant-derived products. Journal of Agricultural and Food Chemistry, 53(5), 1370-1373. https://doi.org/10.1021/jf048396b

Godoy de RCB, Matos ELS, Amorim TDS, De Sousa Neto MA, Ritzinger R, Waszczynskyj N (2008) Avaliação de genótipos e variedades de acerola para consumo in natura e para elaboração de doces. Boletim CEPPA, v.26, n.2, p.197-204.

Gomes JE, Perecin D, Martins AB G, Almeida EJD (2000) Variabilida de fenotípica em genótipos de acerola. Pesquisa Agropecuária Brasileira, 35(11), 2205-221.

Gonzaga Neto L, Mattuz B, Santos CAF (1999) Caracterização agronômica de clones de aceroleira (Malpighia spp) na Região do Submédio São Francisco. Revista Brasileira de Fruticultura, Jaboticabal, v.21, n.2, p.110-115.

Granato D, Katayama,FCU, Castro IA (2010) Assessing the association between phenolic compounds and the antioxidant activity of Brazilian red wines using chemometrics. LWT-Food Science and Technology, 43(10), 1542-1549. https://doi.org/10.1016/j.Iwt.2010.05.031

Hanamura T, Uchida E, Aoki H (2008) Changes of the composition in acerola (Malpighia emarginata DC.) fruit in relation to cultivar, growing region and maturity. Journal of the Science of Food and Agriculture, 88.10: 1813-1820. DOI: 10.1002/jsfa.3285

Instituto Brasileiro de Frutas - IBRAF (1995) Soluções fruta a fruta: acerola. São Paulo: IBRAF.

Lima PCC, Souza BS, Souza PS, Borges SDS, Assis MDOD(2014) Caracterização e avaliação de frutos de aceroleira. Revista Brasileira de Fruticultura, 36(3), 550-555. https://doi.org/10.1590/0100-2945-336/13

Page 14/22 
Loápez AP (1963) Relation of maturity to some fruit characters of the West Indian cherry. Journal of the Agricultural of the University of Puerto Rico, 47, 193 \pm 200 .

Lutz A (1985) Normas Analíticas do Instituto Adolfo Lutz. Métodos químicos e físicos para analise de alimentos, 2.

Maciel MIS, Mélo E, Lima V, Souza KA, Silva W(2010) Caracterização físico-química de frutos de genótipos de aceroleira (Malpighia emarginata DC). Food Science and Technology, 30(4), 865-869. https://doi.org/10.1590/S0101-20612010000400005

Magalhães DS, Rufini JCM, Albuquerque AS, Viol RE, Fagundes MCP, Menezes TP (2018) Genetic diversity among accessions of acerola based on the quality of fruits. Comunicata Scientiae, Volume 9, Issue 2, 2018, Pages 133-141. https://doi.org/10.14295/CS.v9i2.2961.

Mariano-Nasser FDC, Nasser MD, Furlaneto KA, Ramos JA, Vieites RL, Pagliarini MK (2017) Bioactive compounds in different acerola fruit cultivares. Semina: Ciências Agrárias (Londrina), 38(4 Suppl. 1), 2505-2514. DOI: 10.5433/1679-0359.2017v38n4Supl1p2505

Matta LBD, Tomé LGO, Salgado CC, Cruz CD, Silva LDF (2015) Hierarchical genetic clusters for phenotypic analysis. Acta Scientiarum. Agronomy, 37(4), 447-456. https://doi.org/10.4025/actasciagron.v37i4.19746

McGuire RG (1992) Reporting of objective color measurements. HortScience, 27, 1254-1255.

Mezadri T, Villaño D, Fernández-Pachón MS, García-Parrilla MC, Troncoso AM (2008) Antioxidant compounds and antioxidant activity in acerola (Malpighia emarginata DC.) fruits and derivatives. Journal of Food Composition and analysis, 21(4), $282-290$.

doi:10.1016/j.jfca.2008.02.002

Mihaljevic R, Schön CC, Utz HF, Melchinger AE (2005) Correlations and QTL correspondence between line per se and testcross performance for agronomic traits in four populations of European maize. Crop science, 45(1), 114-122. https://doi.org/10.2135/cropsci2005.0114a

Mondragón-Cortez P, Ulloa JA, Rosas-Ulloa P, Rodríguez-Rodríguez R, Resendiz Vázquez JA (2013) Physicochemical characterization of honey from the West region of México. CyTA - Journal of Food, 11(1), 7-13. https://doi.org/10.1080/19476337.2012.673175

Moura CFH, Alves RE, de Figueiredo RW, de Paiva JR (2007) Avaliações físicas e físico-químicas de frutos de clones de aceroleira (Malpighia emarginata DC). Revista Ciência Agronômica, 38(1), 52-57.

Moura NF, Chaves LJ, Naves RV (2013) Caracterização física de frutos de pequizeiro (Caryocar brasiliense Camb.) do cerrado. Revista Árvore 37: 905-912.

Musser RDS, Lemos MA, Lima VLA GD, Mélo ED A, Lederman IE, Santos VFD (2004) Características físico-químicas de acerola do banco ativo de germoplasma em Pernambuco. Food Science and Technology, 24(4), 556-561. https://doi.org/10.1590/S0101-

20612004000400013

Nakasone H Y, Miyashita RK, Yamane GM (1966) Factors affecting ascorbic acid content of the acerola (Malpighia glabra L.). In Proceedings of the American Society for Horticultural Science, Alexandria (Vol. 89, pp. 161-166).

Nascimento JF, dos Santos Barroso B, Tostes EDSL, da Silva ADSS, da Silva Júnior A C S (2018) Análise físico-química de polpas de acerola (Malpighia glabra L.) artesanais e industriais congeladas. PubVet, 12, 131.

Nasser MD, Zonta A (2014) Caracterização de frutos de genótipos de aceroleira em função de estádios de maturação. Tecnologia \& Ciência Agropecuária, v. 8, n. 5, 76-78.

Oliveira JG, Gomes Filho A, Pereira MG, Viana AP, Souza Filho GA, Lopes GEM (2009) Diversidade genética de aceroleiras (Malphigia emarginata D.C.), utilizando marcadores moleculares RAPD e características morfoagronômicas. Revista Brasileira de Fruticultura, v.31, n.1, p.162-170. https://doi.org/10.1590/S0100-29452009000100023.

Oliveira LDS, Moura CFH, De Brito ES, Mamede RVS, De Miranda MRA (2012) Antioxidant metabolism during fruit development of different acerola (Malpighia emarginata DC) clones. Journal of Agricultural and Food Chemistry, 60(32), 7957-7964. dx.doi.org/10.1021/jf3005614

Portarena S, Leonardi L, Scartazza A, Lauteri M, Baldacchini C, Farinelli D, Famiani F, Ciolfi M, Brugnoli E (2019) Combining analysis of fatty acid composition and $\delta 13 \mathrm{C}$ in extra-virgin olive oils as affected by harvest period and cultivar: Possible use in traceability studies. Food Control 105: 151-158. https://doi.org/10.1016/j.foodcont.2019.05.029. 
Prakash A, Baskaran R (2018) Acerola, an untapped functional superfruit: a review on latest frontiers. Journal of Food Science and Technology, 55(9), 3373-3384. https://doi.org/10.1007/s13197-018-3309-5

Reis EF, Pinto JFN, da Assunção HF, da Silva D F P (2017) Diversidade genética de frutos de macaúba provenientes de 35 municípios de Goiás. Pesquisa Agropecuária Brasileira, 52: 277- 282. https://doi.org/10.1590/s0100-204x2017000400008.

Rekha C, Poornima G, Manasa M, Abhipsa V, Devi JP, Kumar HTV, Kekuda TRP (2012) Ascorbic acid, total phenol content and antioxidant activity of fresh juices of four ripe and unripe citrus fruits. Chemical Science Transactions, 1(2), 303-310. DOI:10.7598/cst2012.182

Ribeiro BS, de Freitas S T (2020) Maturity stage at harvest and storage temperature to maintain postharvest quality of acerola fruit. Scientia Horticulturae, 260, 108901. https://doi.org/10.1016/j.scienta.2019.10890

Ritzinger R, Ritzinger CHSPR (2011) Acerola. In: Rodrigues MGV, Dias MSC Cultivo tropical de fruteiras. Informe Agropecuário, v.32, n.264, p.17-25.

Ritzinger R, Ritzinger CHSP, Fonseca N, Machado CF (2018) Advances in the propagation of acerola. Revista Brasileira de Fruticultura, v.40, n.3, e-928. https://doi.org/10.1590/0100-29452018928.

Rohlf F J, Fisher DR (1968) Tests for hierarchical structure in random data sets. Systematic Biology, 17(4), 407-412.

Santos S M, De Vasconcelos AM, Oliveira VS, Clemente E, Costa J M (2012) Evaluation of physical and physicochemical characteristics of Malpighia emarginata DC from the state of Ceará. International Journal of Biochemistry Research \& Review, 2(4), $152-163$.

Segtowick ECDS, Brunelli LT, Venturini Filho WG (2013) Avaliação físico-química e sensorial de fermentado de acerola. Brazilian Journal of Food Technology, v. 16: 147-154. https://doi.org/10.1590/S1981-67232013005000015

Semensato LR, Pereira AS (2000) Características de frutos de genótipos de aceroleira cultivados sob elevada altitude . Pesq. agropec. bras., Brasília, v.35, n.12, p.2529-2536

Seymour GB, Tucker GA (1993) Avocado. In Biochemistry of fruit ripening (pp. 53-81). Springer, Dordrecht, p.53-81.

Silva Freitas RV, de Souza PA, Coelho EL, Silva M S, Batista EM, Ferreira EDO (2012) Caracterização físico-química de variedades de acerolas em dois estádios de maturação. In VII CONNEPI-Congresso Norte Nordeste de Pesquisa e Inovação.

Silva VA, Machado JL, Resende JC, Oliveira AL, Figueiredo UJ, Carvalho GR, Ferrão MAG, Guimarães RJ (2017) Adaptability, stability, and genetic divergence of conilon coffee in Alto Suaçuí, Minas Gerais, Brazil. Crop Breeding and Applied Biotechnology 17: 25-31.

Souza KOD, Moura C F H, Brito ESD, Miranda MRAD (2014) Antioxidant compounds and total antioxidant activity in fruits of acerola from cv. Flor Branca, Florida Sweet and BRS 366. Revista Brasileira de Fruticultura, 36(2), 294-304. https://doi.org/10.1590/0100-2945-410/13

Streit M, Gehlenborg N (2014) Bar charts and box plots. Nat Methods 11, 117. https://doi.org/10.1038/nmeth.2807

Vendramini A L, Trugo L C (2000) Chemical composition of acerola fruit (Malpighia punicifolia L.) at three stages of maturity. Food Chemistry, 71(2), 195-198. https://doi.org/10.1016/S0308-8146(00)00152-7

Viúda-Martos M, Ruiz-Navajas Y, Zaldivar-Cruz JM, Kuri V, Fernández-López J, Carbonell-Barrachina AA, Pérez-Álvarez JA (2010) Aroma profile and physico-chemical properties of artisanal honey from Tabasco Mexico. International Journal of Food Science and Technology, v.45, n.6, p.1111-1118. https://doi.org/10.1111/j.1365-2621.2010.02243.x

Wahyuningsih S, Wulandari L, Wartono MW, Munawaroh H, Ramelan AH (2017) The effect of pH and color stability of anthocyanin on food colorant. In IOP conference series: Materials science and engineering, Vol. 193, No. 1, p. 12047.

Wise B M, Gallagher NB (1996) The process chemometrics approach to process monitoring and fault detection. Journal of Process Control, $6(6), 329-348$.

Xu M, Shen C, Zheng H, Xu Y, Xue C, Zhu B, Hu J (2020) Metabolomic analysis of acerola cherry (Malpighia emarginata) fruit during ripening development via UPLC-Q-TOF and contribution to the antioxidant activity. Food Research International, $130,108915$.

https://doi.org/10.1016/j.foodres.2019.108915

Page $16 / 22$ 


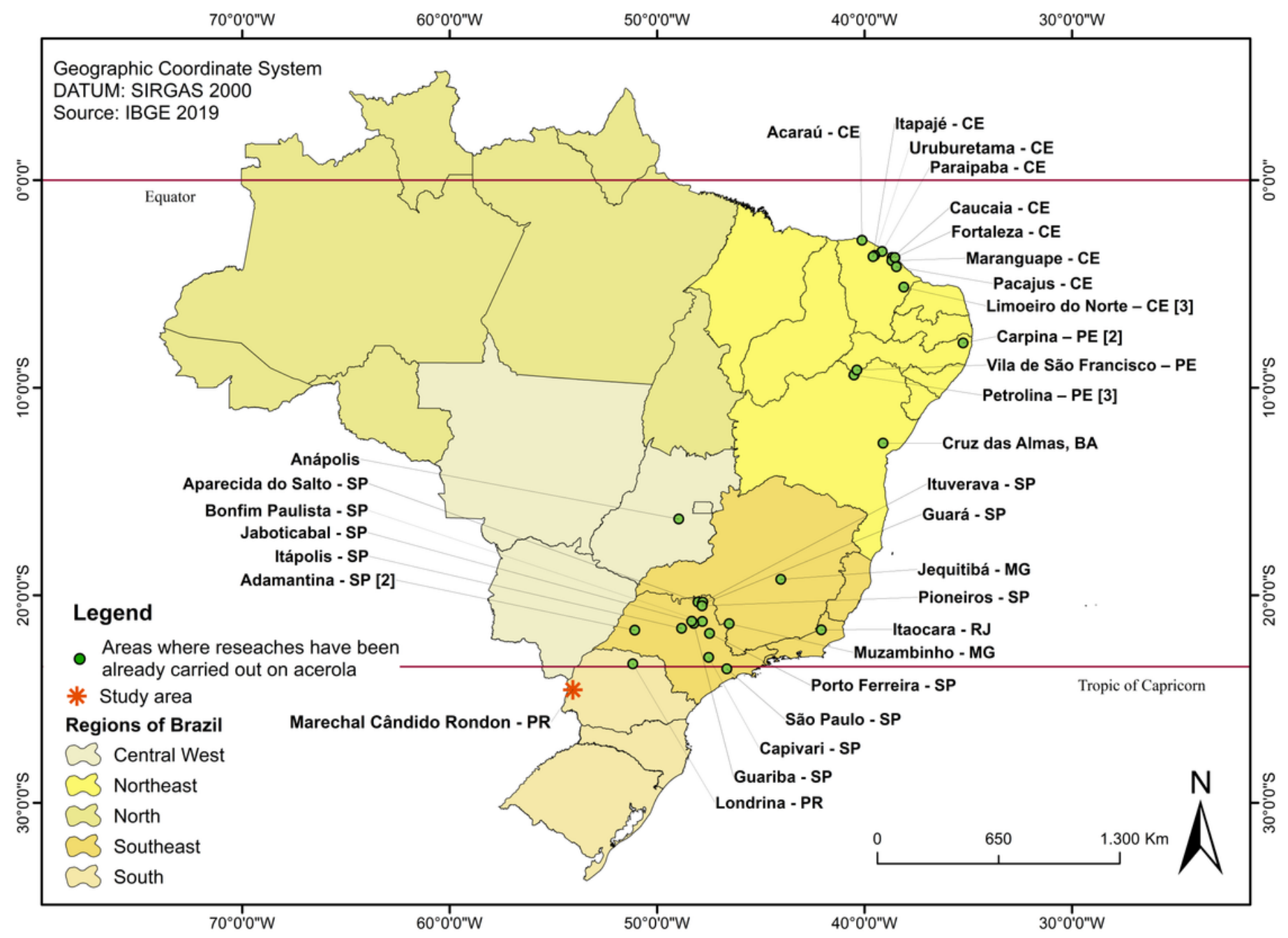

Figure 1

Map of Brazil with symbols indicating the areas where studies were already carried out on acerola. Note: The designations employed and the presentation of the material on this map do not imply the expression of any opinion whatsoever on the part of Research Square concerning the legal status of any country, territory, city or area or of its authorities, or concerning the delimitation of its frontiers or boundaries. This map has been provided by the authors. 


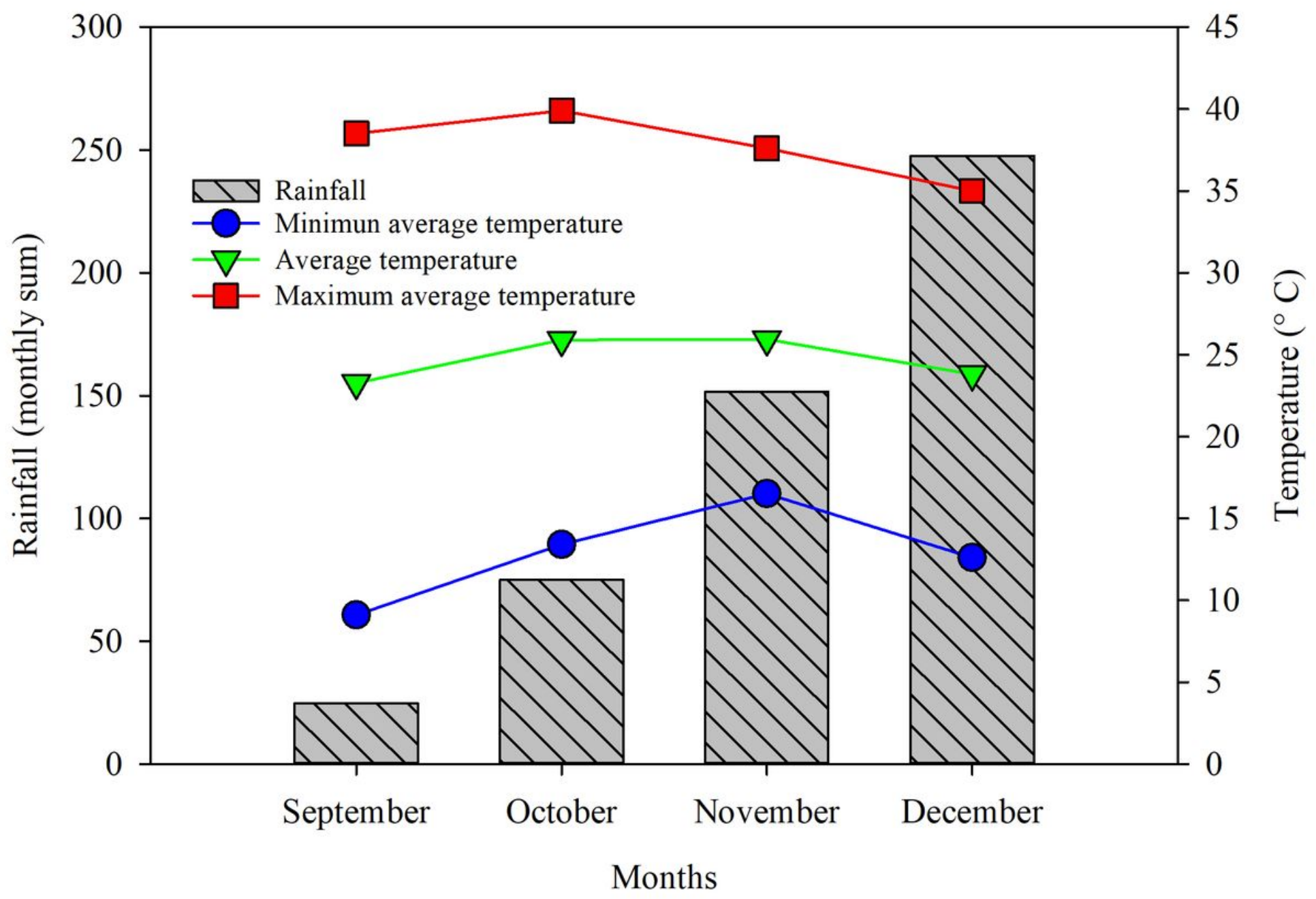

Figure 2

Seasonal variation of maximum/minimum/average temperature, monthly-cumulated rainfalls recorded from October to December 2019. 


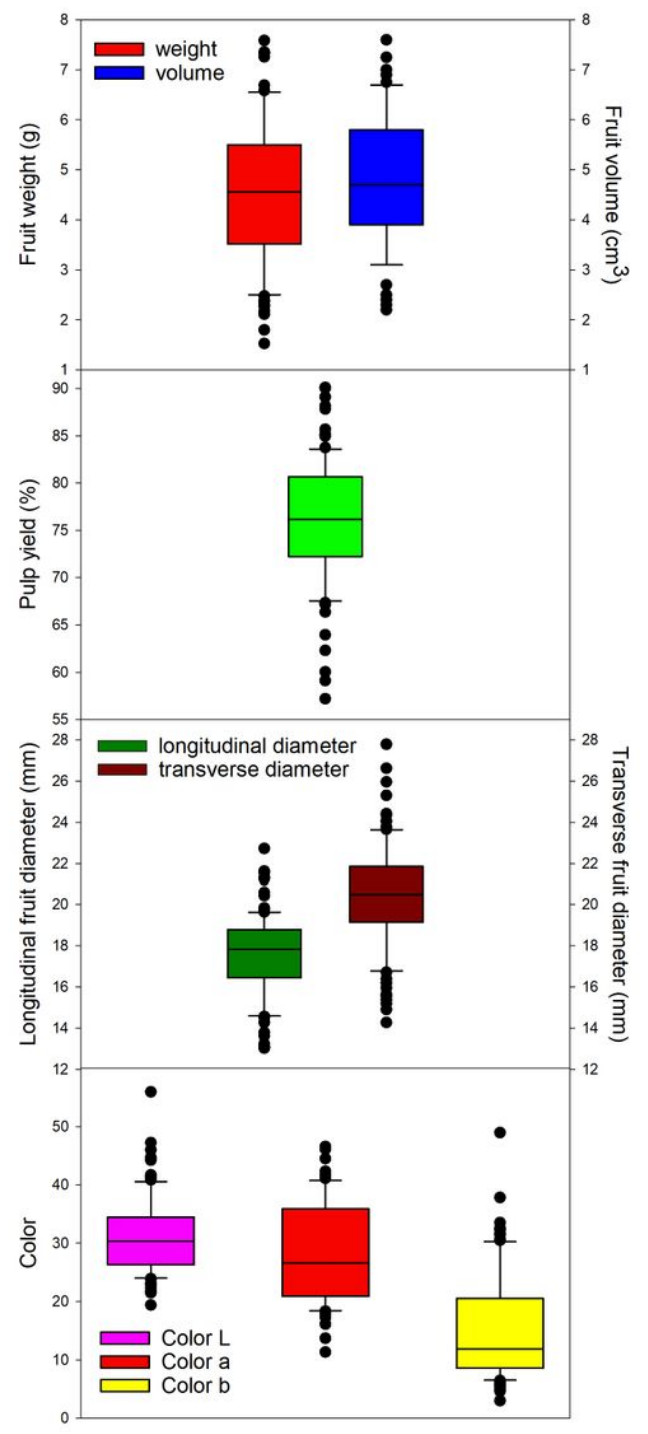

Figure 3

Box plots of physical parameters. Whiskers (error bars) above and below the box indicate the 90 th and 10th percentiles. The horizontal line shows the median value. Symbols display extreme data points. 


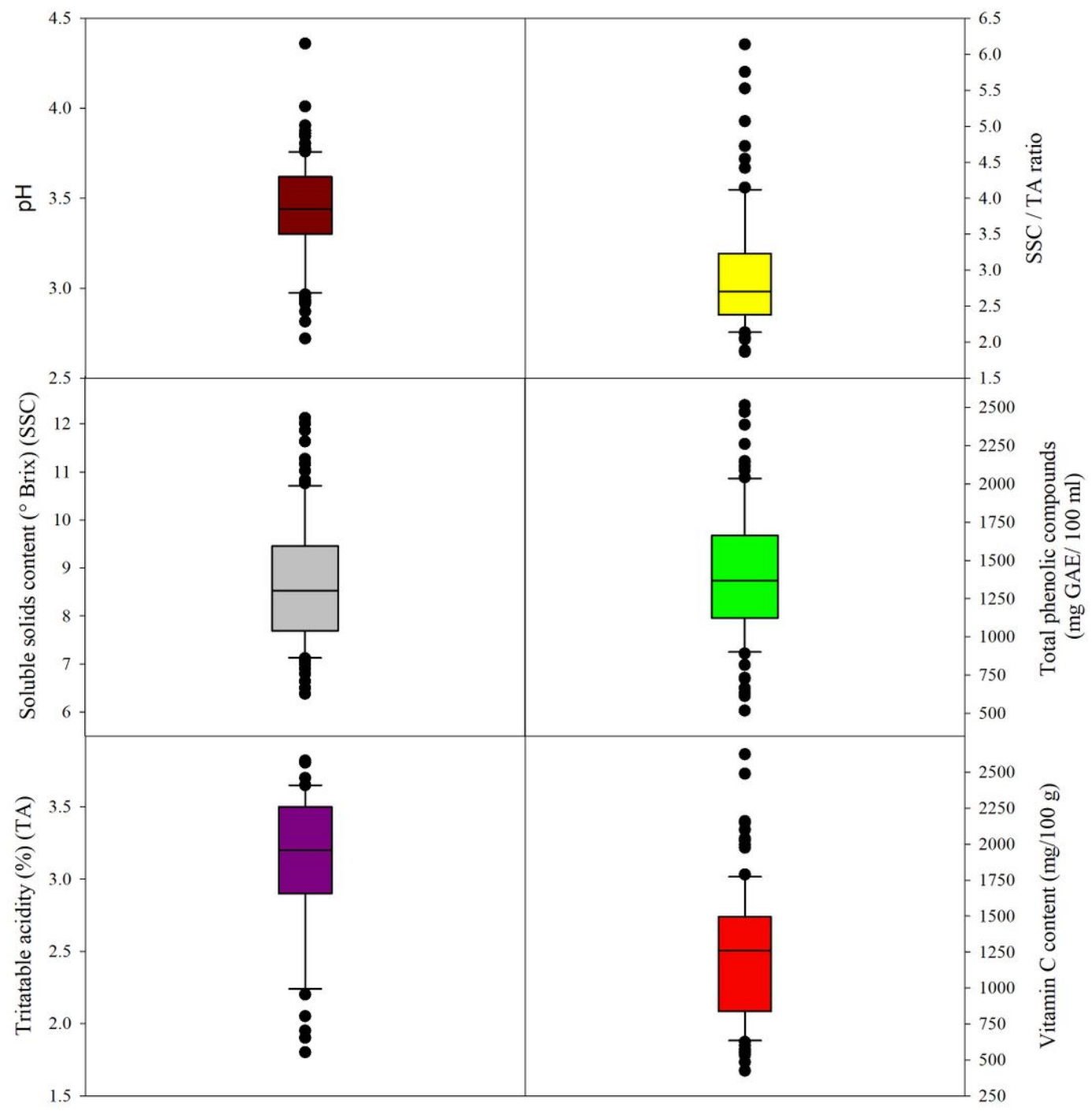

Figure 4

Box plots of chemical parameters. Whiskers (error bars) above and below the box indicate the 90th and 10th percentiles. The horizontal line shows the median value. Symbols display extreme data points. 


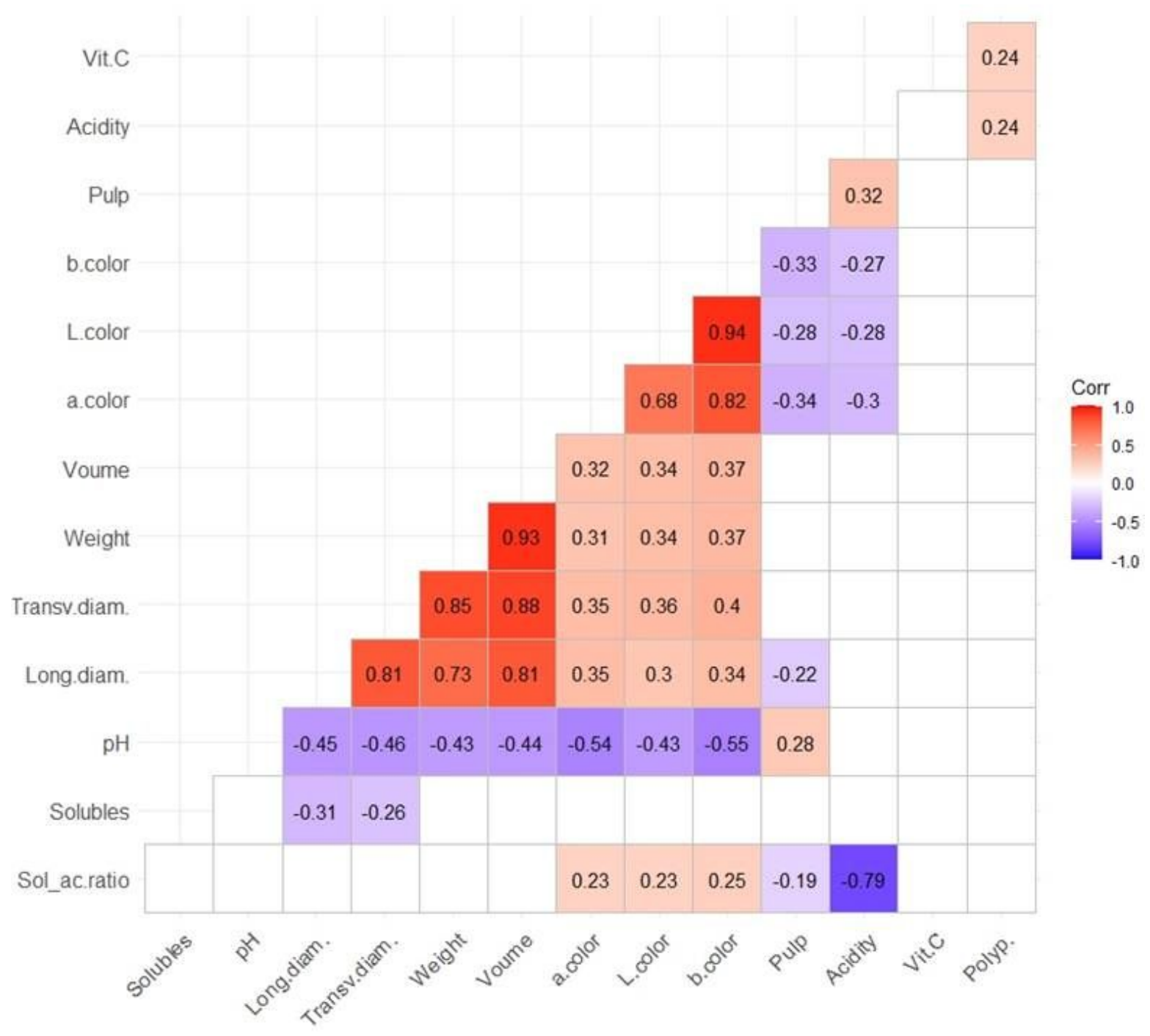

\section{Figure 5}

Pearson's correlations among the principal parameters with statistical significance.
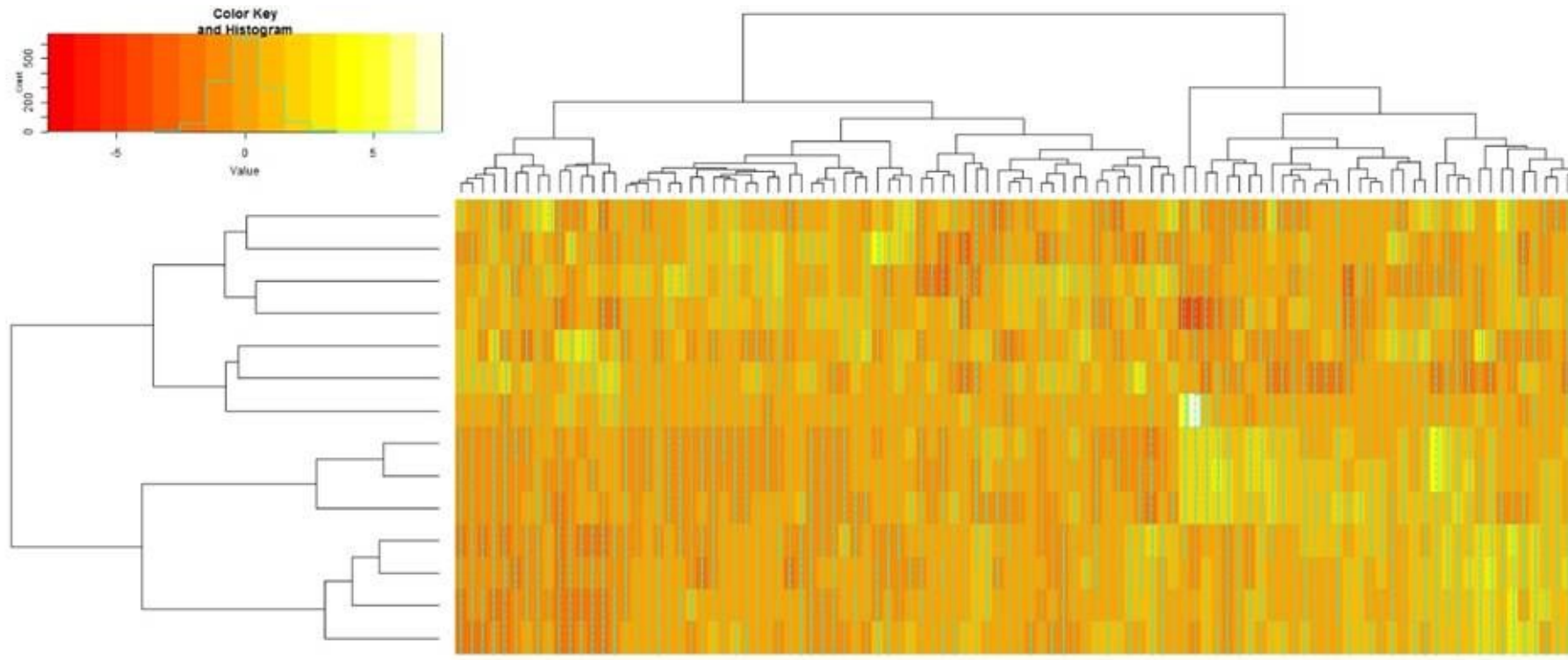
Dendrogram of variables obtained through cluster analysis (Ward's method) representing the Euclidean distances of the 103 acerola phenotypes.

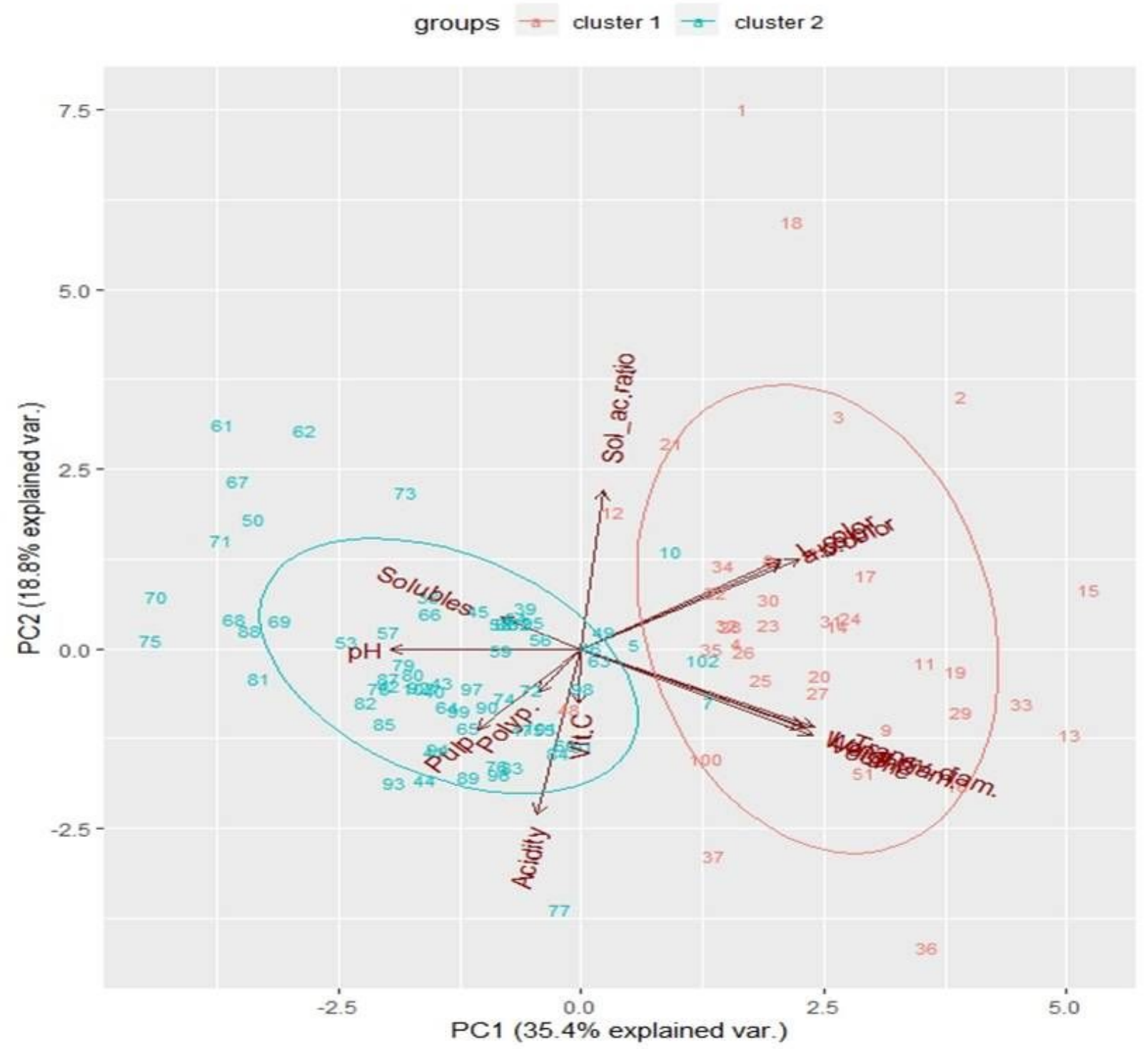

Figure 7

Scatter plot of the scores of acerola samples on the two-dimensional plane defined by the first three PCs as calculated from the complete dataset by PCA. Samples are grouped according to the HCA results (the confidence level of 0.95 defines the ellipses in such manner that approximately $95 \%$ of the new observations from that group fall inside the ellipse).

\section{Supplementary Files}

This is a list of supplementary files associated with this preprint. Click to download.

- Photo114421.jpg

- TableS.114421.docx

- TableS.214421.docx

- TableS.314421.docx 